\title{
Essay
}

\section{Accelerating Curve of Anxiousness}

How a Governmental Quarantine-App Feeds Society with Bugs

\author{
Aleksandra Bartoszko \\ VID Specialized University
}

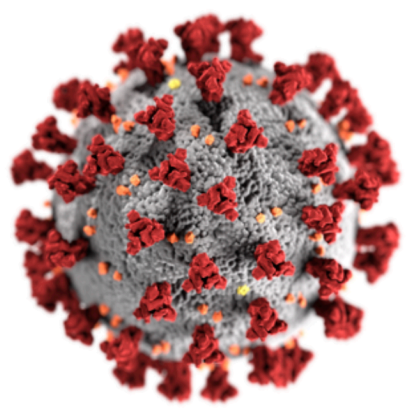

Daily, media reports on countries eagerly introducing advanced surveillance technology to counter the COVID-19 pandemic (e.g. Byers 2020, Doffman 2020; Holmes 2020, Stojanovski 2020). The critics and commentators focus - rightly on multifaceted dangers lurking behind the technological optimism, which drive our hopes of defeating the pandemic (e.g. Cahn and Veiszlemlein 2020; Ikeda 2020; Swire 2020). Majority of the critical voices concerns the future risks, and the (unintended) consequences of the implemented products, which do their (intended) job. But some technological interventions not only have unintended consequences, they simply do not work. A case in point: a Polish bugged app. Considering this app, I invite the readers to a discussion about how a bugged app may impact social relations, citizen's wellbeing and sense of (in)security in the already disturbed political and health context.

In Poland, until the $31^{\text {st }}$ of March 2020, persons covered by a 14-day compulsory quarantine ${ }^{1}$ had two choices: daily police $\operatorname{check}(\mathrm{s})$ or surveillance using a special

${ }_{1}^{1}$ Not complying with the quarantine rules results in fine from 500 PLN (\$1 18) up to 30.000 PLN (\$7300). 
mobile app. But on that day, the government imposed emergency legislation and the app was made compulsory for every person in registered isolation (with few exceptions, such as visual impairments). The app requires people in quarantine for COVID-19 to periodically send selfies on request to prove they are not violating isolation. The procedure sounds simple: you install the application on your smartphone, allow access to the location of the device and take a selfie. Several times a day, at different times, users receive a notification to confirm that they are in a quarantine. The application is connected to the data registry of people quarantined. On this basis it verifies whether the address and image of the person in the register coincides with the one from which the device transmits.

The information about the purpose of the app is not clear and the official messages are conflicting. On the one hand, the Ministry says it is designed to help the persons in quarantine to connect to required services and gather information about the COVD-19, on the other - if not more frequently - it emphasizes that it is designed to relieve police in verifying if the quarantine rules are not violated (Ministerstwo Cyfryzacji 2020a, 2020b). Clearly, this is an app of distrust.

The app was developed by the Ministry of Digital Affairs (Ministerstwo Cyfryzacji) in cooperation with the Ministry of Health and commercial actor TakeTask2. Kwarantanna Domowa (Home Quarantine) is a modified app created for market research and task management in large companies, allowing, for example, ordering specific activities such as taking a picture of a shop window or placing products on the shelves. In the original app agents turn into mysterious clients. In Kwarantanna Domowa, the customer is the state while the agent is the person quarantined (Suteniec 2020).

Last week, the Ministry emphasized that the installation of the app was voluntary, and it existed as an alternative and supplement to the random checks of quarantine compliance by the police and sanitary department. Piotr Mieczkowski, managing director of the Digital Poland foundation said: 'It is worth noting that in Poland the use of this application is voluntary and if someone does not trust the state, they do not have to use it' (Sutaniec 2020). However, the app is now mandatory and as pointed out by the Panoptykon Foundation, such a solution potentially breaks with the Polish constitution, particularly if the code of the app is not open (Szymielewicz and Obem 2020). It is also alarming that police required the installation, falsely informing citizens before the legislation passed. As one user commented: 'Today I also received information from the police that "since yesterday there is an obligation to install the application, even if it does not work properly, please install"'.

2 TakeTask has now earned 2,5 million PLN (\$610.000) from this project (Szczygiel 2020). 


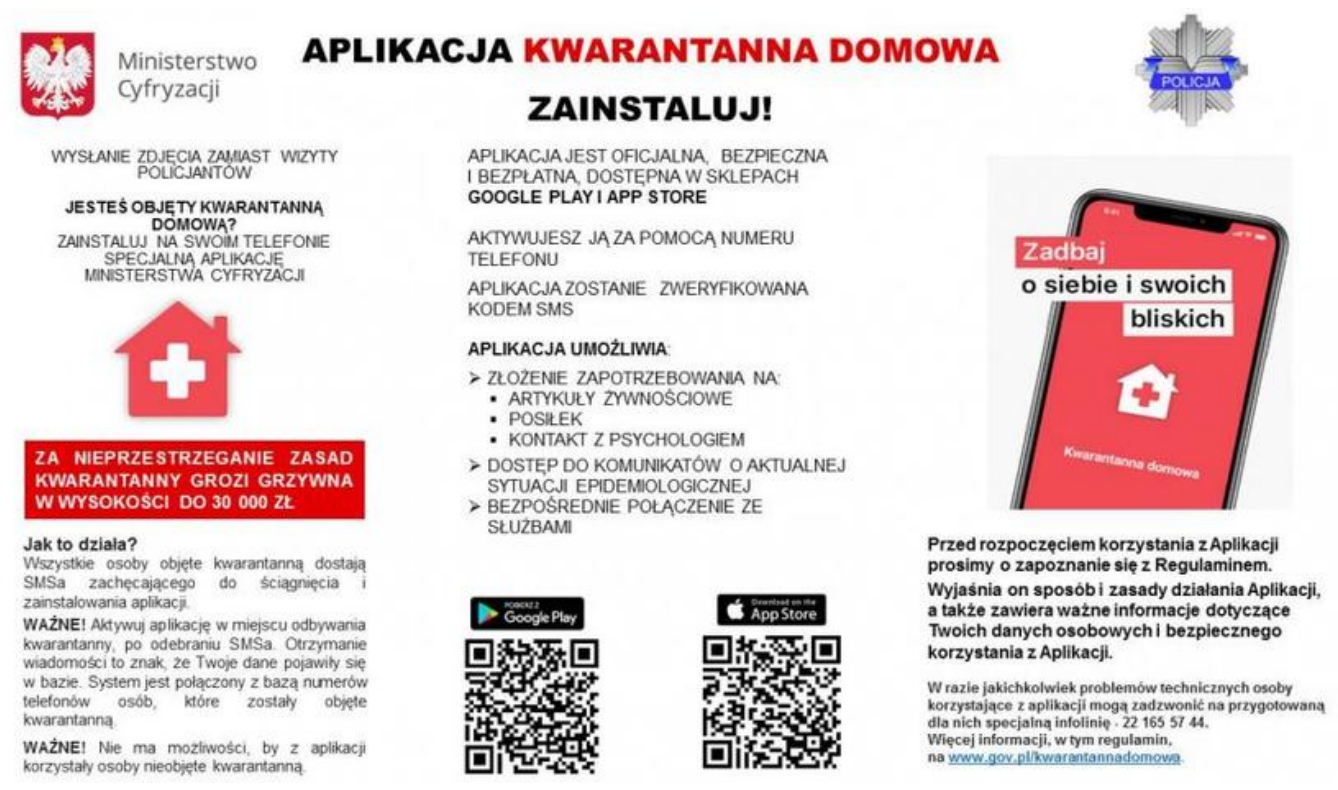

Information pamphlet issued by the Ministry of Digital Affairs

\section{Anatomy of Risks}

Not unlike other surveillance initiatives, this governmental project suffers from a lack of transparency. For instance, the app has wider rights and functions than mentioned in the regulations on the governmental website or those attached to the app. We learn about them from the permissions in the Google Play/App store and from IT experts reading the codes. Tomasz Zielinski (Zielinski 2020) dissecting the codes found also that the app is integrated with Facebook libraries and a media player. The Ministry has not answered if the app communicates in any way with the Facebook infrastructure.

The commercial version of the app, on which Kwarantanna Domowa is based, says that all data sent by the users is automatically collected on a dedicated server. However, nobody knows where it is located and to whom it belongs, and to my knowledge the Ministry has not answered these questions either. While some institutions such as the Central IT Center, General Police Headquarters, Voivodship Police Headquarters, Voivods or Center for Health Care Information Systems can be associated with the epidemiological objective of the app, it may be different with the intelligence agency. This access is not mentioned in the application regulations either. In Poland, as soon as state security is at stake, the scope of regulations, statutes and ordinances that protect the rights of citizens is limited. The Intelligence agency is not covered by any provisions regarding the protection of personal data. In practice, this means that they can obtain all information they consider useful for carrying out their tasks. If the location data and photos sent by users of the app are kept longer by any of the authorized institutions, the intelligence agency may intercept them for other purposes (Szymielewicz and Obem 2020). For example, to train algorithms for facial recognition without users' 
knowledge and consent, a situation with a long and documented history (e.g. Captcha or FaceApp).

The data obtained by the app will be stored for six years. The Ministry of Digital Affairs has lately assured that at least photos of users will be deleted after quarantine (Szymielewicz and Obem 2020). However, the ministry announced that the app is voluntary, which already a week after its launch is in question. In the context of a government with authoritarian tendencies, which does not refrain from breaking human rights, constitution, constantly undermine the rule of law and judicial independence (e.g. Human Rights Watch 2019), the anxiety of misusing the data and risk of algorithms being used in a completely different context (e.g. identifying protesters) is justified.

For now, however, let us look away from the legal aspects of the app and dangers of future misuse, and look at some current societal consequences of the state's blind faith in technology and datafied knowledge.
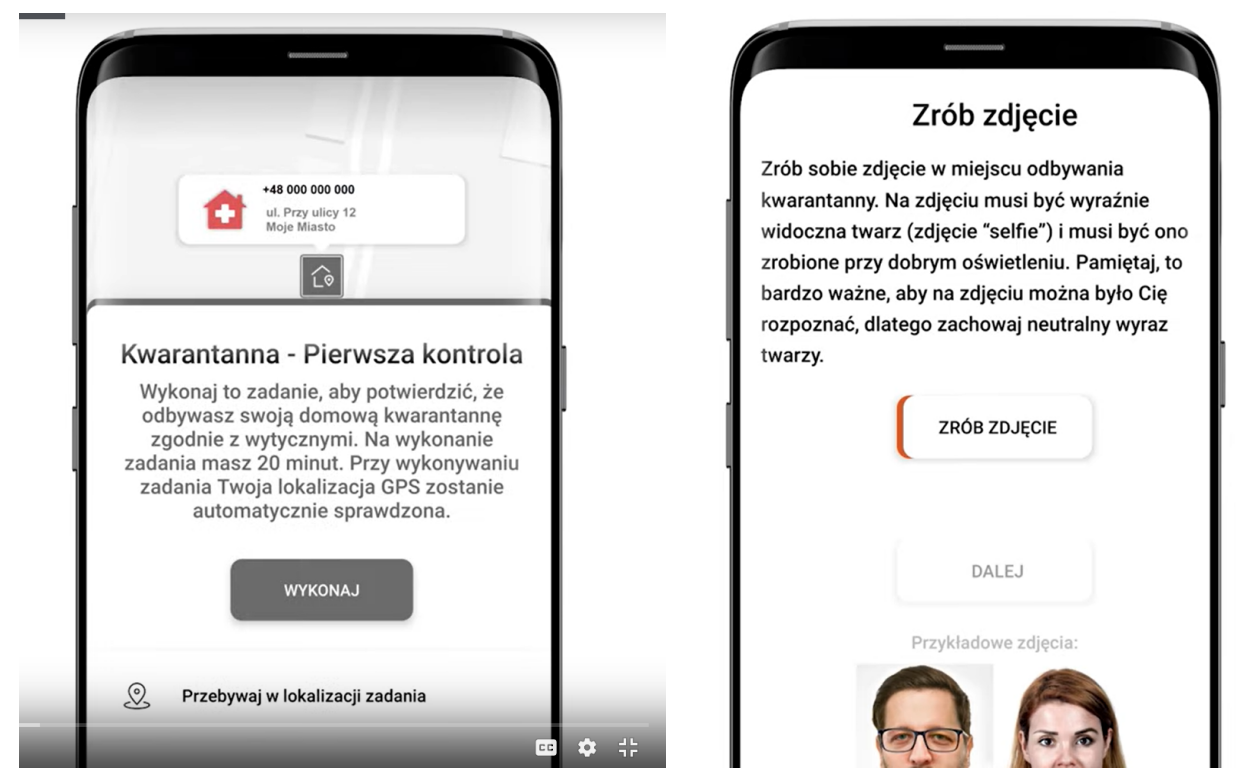

Screenshots from tutorial issued by the Ministry of Digital Affairs:

https://www.youtube.com/watch?time continue $=4 \& v=W g$ SsmkHU7M\&feature $=e m b-$ $\underline{\log 0}$

\section{Governing Bugs}

After downloading the app and filling out personal information, the user is informed that they will randomly receive two SMS daily requiring to "complete the task" (take selfie, confirming their location). A quick look on the comment section at the Google Play and Appstore as well as first reports in media reveals the frus- 
tration among many of the now more than 30.000 users of the app ${ }^{3}$. As one of the users warned: 'It's bugged as hell. Don't install it. Fust nerves and waste of time. I am deleting it'. Opting out of the app is not possible, however:

You cannot. It's a one-way ticket. If you have already decided on this form of control in this extraordinary situation, you must use it until the end of the 14-day period. Uninstalling the application from your phone will not do anything, because text messages with reminders will still be coming (Warsinski 2020).

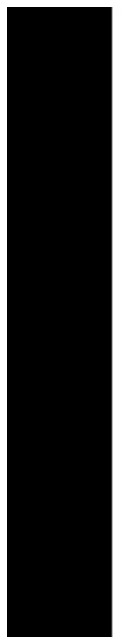

\section{Jeśli nie wykonasz zadania we wskazanym czasie, wyślemy Ci przypomnienie.}

\section{SMS}

\section{Nadawca: Kwarantanna} Wykonaj zadanie $\mathrm{w}$ aplikacji Kwarantanna domowa. Masz jeszcze 10 minut.
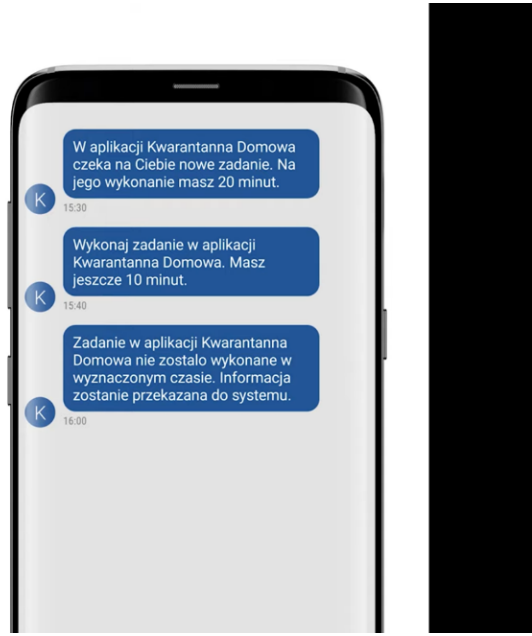

Screenshot from tutorial issued by the Ministry of Digital Affairs:

https://www.youtube.com/watch?time continue $=4 \& v=W g$ SsmkHU7M\&feature $=e m b$ $\underline{\log 0}$

\section{The Countdown of Care and Punishment}

The way the public institutions marked the app indicates that it is not designed as a tool for care. The aesthetics of fear and panic is striking too. Elements such as frequently used exclamations marks and capital letters reminding of charging the phone and not muting the device, as well as red colored warnings about informing police or 'the system' (unclear which system) are dominating. These are symbols of threat, sending signals opposite to sense of security and undermining the impression of the police or 'the system' as caring partners. As one of the users commented:

The app focuses on control and potential punishment, not on supporting and reassuring me that I'm doing right. And the

\footnotetext{
${ }^{3}$ The number will surely raise significantly after the app is no longer voluntary.
} 
worst is the text, which is supposed to support: 'By using the app, you protect your loved ones.' No, staying at home can protect someone, using the app does not guarantee it.

Further, the app does not provide necessary contacts if a user needs one. The functions such as contact with social workers, psychologists or help with grocery shopping are not working: 'I have not been contacted by the services I requested', 'Useless. A classical scarecrowe, additional control over society.'

For a person in quarantine with the app, at a random point of the day (or even night), the text massaging avalanche starts: The first SMS reads that the user has 20 minutes to 'complete the task'. After 10 minutes, new SMS alarms ' 10 minutes to completing the task'. After that, SMS reads 'You have not completed the task, information is set to the system'.

\title{
Informacja na ten temat trafi do systemu.
}

\author{
To znak dla policji, \\ aby Cię odwiedzić.
}

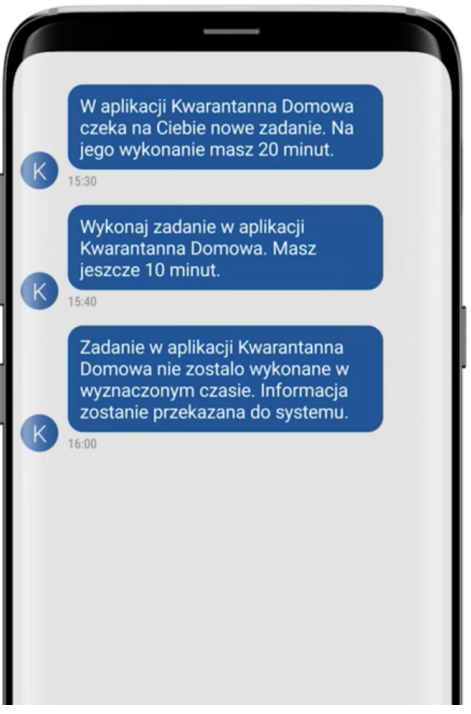

Screenshot from tutorial issued by the Ministry of Digital Affairs:

https://www.youtube.com/watch?time_continue $=4 \& v=W g$ SsmkHU7M\&feature $=e m b \_$$\underline{\log 0}$

This countdown is particularly stressful to the users:

The app shows the task to be completed (selfie) 14 minutes after receiving the text, i.e. 6 minutes to complete the task. This is very stressful because it brings us closer to the chance of not doing it due to lack of time. Despite the selfie made and sent, I received a text saying that the task was not completed. What should I think about it? 
Reportedly, the app often does not register the tasks or after sending out SMS requesting the task, the app says 'no more tasks'. For many, 'It's very stressful as you have limited time to complete it, but you can't even do it.' Users felt frustrated and disappointed as the app unnecessary puts them under suspicion:

Me and my wife are in quarantine and we installed this app only one check worked so far - others not. Getting SMS about new 20 min task and app says you don't have new tasks. And later you receive SMS that you didn't accomplish check in - information was passed to the system. It's a bit stressful as we really are sitting at home without throwing our trash for one week already. Come on people!

\section{Available Citizens}

Because the app is constructed around the randomness and stressful counting down, the users' needs to adjust their (already disturbed) daily routines to it. Some users report that the regulations mention 1-2 SMS daily, while they receive up to 4-5 requests daily and feel therefore forced to hold the phone next to them all the time, which is distressing for many reasons. In addition, the app's requirements of constant availability make citizens discipline and adjust their bodies and its needs to the double-policing (SMS and police visiting). Such as users reporting sleeping over the SMS or 'failing task' because of changing diapers or taking shower. One user received a phone call from a friend: 'After the conversation I look at the text saying that I missed this time and my inactivity has been reported. - It scared me.' Other user was so worried about missing the next task that she stopped taking her naps despite her bad health. In addition to the fact that psychological stress that can manifest itself physically deteriorating already weak health, sick citizens refrain from recommendations concerning how to take care of themselves during the crisis. This puts in question if the app is an appropriate tool for caring for public health. It surely has potential of causing harms.

\section{"I don't lie, data do"}

The most common is location error. The tool is inaccurate, and the range of acceptable GPS position is confusing, which may give an impression that the person submitting their photo has left the quarantine location. Despite the error not being solely a failure of the app itself, but rather depending on the equipment used by the person, it still puts the whole project into question:

Using it is practically impossible. Even though I am sitting at home all the time, it displays error 463, which suggests that I am in a different location. I wanted to support the control services, but it is impossible.

As there is no information available to the user regarding period of quarantine, the user experience inaccuracies and sense of confusion: 
How do I know if this is consistent with my calculations?? I got a text message a few days after crossing the border! The chaos is because the sanitary department and police have different ranges. I don't know which period is registered in the application, and even if I knew there is no way to change it.

These examples illustrate too perils of technology and data-driven governance. The burden of proof is now on the individuals. In a context of the increasing faith in data as 'evidence' and an unerring tool of control and decision making, the individuals already exposed to, for instance political persecution or prejudice, may be subjected to unjust treatment.

\section{Technostress and Techno-insecurity}

In their recent update of the app governmental website, the Ministry added the $\mathbf{Q}$ \& A section responding to the feedbacks on app crushing. It reads:

If after closing the application completely (so that it does not run in the background) this error repeats, you need to enter the phone settings, and then go to Manage applications / Installed applications / Applications (the name depends on the phone model). In the application list, find the 'Home Quarantine' application and then clear the application data. On some phone models, after entering the application you have to go to the default memory to clear the data. If that does not help, uninstall and reinstall the application. The same should be done when error 472 appears and the message: 'This task is already started. Finish or continue' (Ministerstwo Cyfryzacji 2020b).

In other words, the state requires from the citizens digital competence and skills, but also a significant investment of time in order to satisfy the requirements and to fix the bugs. I appreciate that the situation is extraordinary, and it requires extraordinary measures and efforts from institutions and individuals. However, such a requirement of individual responsibility for the technopolitical challenge is disturbing.

The app increases techno-stress among citizens who are nervous and confused about the situation, anxious about losing their race with the app, and not being able to cope with it in a healthy manner (see Brod 1984). This case brings also a new dimension to the phenomenon of techno-insecurity, which is usually associated with situations where people feel threatened about losing their jobs to other people who have a better understanding of new gadgets and computing devices (Tarafdar et al. 2007). Here, the threat is equally real, but the fear regards being visited by the police, receiving fine or having their data misused.

Yes, people in Poland report about police visiting and checking the situation anyhow, but receiving an individual message informing about person's individual fail- 
ure reported to 'the system' is experienced as more disturbing than the sight of the police on the streets:

It's not like I am afraid of the police, they are OK. But this whole situation makes me anxious. You know, the SMS telling you that you did not complete the task so the system will know. This gives me bad associations.

\section{The Double Burden of Control}

The double-policing regards not only the ways the Polish government has chosen to check if the quarantine rules are obeyed, but also the double usage of resources due to the buggy app. Either because of 'not completing the task' or despite doing it several times a day, some people are visited by the police every day. The most ironic is that the same citizens installed this app to relieve the police. Here is a sample of experiences illustrating the local challenges for both police and the app users:

I have the impression that the amount of police checks I have increased with this application. Today, until 13:30, I had 3 patrols.

The app as such is all right and it worked well. But the local police doesn't know it exists and they keep coming to check us anyway.

I have been using [the app] for 5 days, I take a selfie and the police visit me anyway because they are not connected to the application! Why add the stress and extra work?

Useless app, police is checking me daily so now I've got a double nuisance.

There are no official reports from the police departments, however it seems legit to assume that the broken technology causes additional workload for the police officers.

\section{Bugs of Trust}

'We have created this application to make the mandatory home quarantine easier', explained Minister of Digital Affairs Marek Zagórski (Ministerstwo Cyfryzacji 2020b). So far, this technological solution has not achieved this goal. On the contrary, it makes the citizens living in already disturbing situation, more stressed and anxious. When proposing a new control tool, democratic governments must consider whether the intrusive means are the only way to achieve the goals. The Polish government has not yet provided any evidence that Kwarantanna Domowa is sensible and effective. As far as users' experience tell, rather than facilitating the fight 
against a pandemic, it makes daily life of the police forces and citizens in quarantine more difficult and unbearable emphasizing that the state treats them with genuine suspicion. As the bugs increase so does the distrust toward the government's response to COVID-19 and towards its ability and willingness to solve the crisis.

Researchers and politicians around the globe are engaged in constructing models and prognosis for the development of COVID19, as well as predicting effects and side-effects of the introduced measures. The critical investigation and predictions of the technology-based measures should be included in these discussions. In societies with a reciprocal distrust between the state and the citizens, the technological failures accelerate the dysfunctional character of pandemic measures.

\section{References}

Brod, Craig. 1984. Technostress: The Human Cost of the Computer Revolution. Reading, Mass.: Addison Weslety.

Byers, Dylan. 2020. 'The U.S. wants smartphone location data to fight coronavirus. Privacy advocates are worried.' NBS News, 18.03.2020. https:// www.nbcnews.com/tech/tech-news/u-s-wants-smartphone-location-datafight-coronavirus-privacy-advocates-n1162821.

Cahn, Albert Fox, and John Veiszlemlein. 2020. 'COVID-19 tracking data and surveillance risks are more dangerous than their rewards.' NBS News, 19.03.2020. https://www.nbcnews.com/think/opinion/covid-19-trackingdata-surveillance-risks-are-more-dangerous-their-ncna1164281.

Doffman, Zak. 2020. 'Coronavirus Police Surveillance Tags Are Now Here: Hong Kong First To Deploy.' Forbes, 17.03.2020. https://www.forbes.com/sites/ zakdoffman/2020/03/17/alarming-coronavirus-surveillance-bracelets-nowin-peoples-homes-heres-what-they-do/

Holmes, Oliver. 2020. 'Israel to track mobile phones of suspected coronavirus cases.' Gurdian, 17.03.2020. https://www.theguardian.com/world/2020/mar/ 17/israel-to-track-mobile-phones-of-suspected-coronavirus-cases

Human Rights Watch. 2020. "World Report 2019/ Poland". https://www.hrw.org/ world-report/2019/country-chapters/poland

Ikeda, Scott. 2020. 'China Adds COVID-19 Contagion Risk Ratings to Individual Profiles in National Surveillance System.' CPO Magazine, 23.03.2020. https://www.cpomagazine.com/data-privacy/china-adds-covid-19-contagion-risk-ratings-to-individual-profiles-in-national-surveillance-system/.

Ministerstwo Cyfryzacji. 2020a. 'Aplikacja Kwarantanna domowa.' Ministerstwo Cyfryzacji, accessed 30.03.2020. https://www.gov.pl/web/koronawirus/ kwarantanna-domowa.

Ministerstwo Cyfryzacji. 2020b. 'Ponad 10 tysięcy osób korzysta z naszej aplikacji Kwarantanna Domowa! Odpowiadamy na Wasze pytania.' Ministerstwo Cyfryzacji, accessed 30.03.2020. https://www.gov.pl/web/cyfryzacja/pon- 
ad-10-tysiecy-osob-korzysta-z-naszej-aplikacji-kwarantanna-domowaodpowiadamy-na-wasze-pytania.

Radio Tok FM. 2020. 'Aplikacja „Kwarantanna domowa” będzie obowiązkowa? Rzecznik policji mówi o nowej specustawie.' 30.03.2020. https://www.tokfm.pl/Tokfm/7,103085,25823804,wypad-na-myjnie-do-fryzjera-lub-poalkohol-rzecznik-policji.html.

Stojanovski, Filip. 2020. 'COVID-19 pandemic adversely affects digital rights in the Balkans.' Global Voices Advox, 30.03.2020. https://advox.globalvoices.org/2020/03/30/covid-19-pandemic-adversely-affects-digital-rights-inthe-balkans/

Suteniec, Grzegorz. 2020. 'Tajemniczy klient kwarantanny.' Puls Biznesu, 25.03.2020. https://www.pb.pl/tajemniczy-klient-kwarantanny-986385.

Swire, Peter. 2020. 'Security, Privacy and the Coronavirus: Lessons From 9/11.' Lawfare, 24.03.2020. https://www.lawfareblog.com/security-privacy-andcoronavirus-lessons-911? fbclid=IwAR2TIUYzw5dNrBnb_WqUZ2joOU9EIVsFMsLqvBYVVIOwOAguP LijZBc6Z8.

Szczygiel, Konrad. 2020. 'Selfie za 2,5 mln. Prywatna firma ma dostęp do danych Polaków na kwarantannie.' Newsweek Polska, 30.03.2020. https:// www.newsweek.pl/polska/spoleczenstwo/koronawirus-aplikacja-dla-przebywajacych-na-kwarantannie-wysyla-dane-to-prywatnej/ybdjgef.

Szymielewicz, Katarzyna, and Anna Obem. 2020. 'Odpowiadamy na pytania o aplikację „Kwarantanna domowa”.' Panoptykon, 25.03.2020. https:// panoptykon.org/aplikacja-kwarantanna-domowa.

Tarafdar, Monideepa, Qiang Tu, Bhanu S. Ragu-Nathan, and T. S. Ragu-Nathan. 2007. 'The Impact of Technostress on Role Stress and Productivity.' Journal of Management Information Systems 24 (1):301-328. doi: 10.2753/ MIS0742-1222240109.

Warsinski, Maciej. 2020. 'Gdzie trafiają nasze zdjęcia i czy to właściwie działa? Kwarantanna z aplikacją.' TVN24, 28.04.2020. https://tvn24.pl/polska/ koronawirus-w-polsce-jak-dziala-aplikacja-dla-osob-wkwarantannie-4517124.

Zielinski, Tomasz. 2020. 'Aplikacja "Kwarantanna domowa" czyli jak szybko wydać aplikację gdy jest się rządem.' Informatyk Zakladowy, 20.03.2020. https://informatykzakladowy.pl/aplikacja-kwarantanna-domowa-czyli-jakszybko-wydac-aplikacje-gdy-jest-sie-rzadem/ 